\title{
Were the first trace fossils really burrows or could they have been made by sediment-displacive chemosymbiotic organisms?
}

\author{
Duncan McIlroy
}

\author{
Earth Sciences, Bonne Bay Marine Station, Memorial University of Newfoundland, St. John's, NL A0K 3V0, \\ Canada. \\ Email: dmcilroy@mun.ca
}

\begin{abstract}
This review asks some hard questions about what the enigmatic graphoglyptid trace fossils are, documents some of their early fossil record from the Ediacaran-Cambrian transition and explores the idea that they may not have been fossils at all. Most researchers have considered the Graphoglyptida to have had a microbial-farming mode of life similar to that proposed for the fractal Ediacaran Rangeomorpha. This begs the question "What are the Graphoglyptida if not the Rangeomorpha persevering" and if so then "What if...?". This provocative idea has at its roots some fundamental questions about how to distinguish burrows sensu-stricto from the external molds of endobenthic sediment displacive organisms.
\end{abstract}

Keywords: Ichnology; Ediacaran; Cambrian; Rangeomorpha; Graphoglyptida; Endobenthos

\section{Introduction}

The importance of the first colonization of the sedimentary realm by infaunal organisms has been at the heart of discussions around the evolution of complex animal life and the beginning of the Cambrian Explosion of animal life (Crimes \& Anderson 1987; Mcllroy \& Logan 1999; Mcllroy \& Brasier 2017; Buatois 2018). The base of the Cambrian period (and end of the Ediacaran) is defined by the first occurrence of trace fossils belonging to the Treptichnus pedum Assemblage Zone (Brasier et al. 1992; Geyer \& Landing 2017) at a point in rock in Fortune Head in Newfoundland, Canada approx. 540Ma). The precept behind this decision was the recognition that burrowing is an easily preservable-fundamentally animalian - trait either in the form of fossil burrows or burrowing fabrics (e.g. Crimes \& Anderson 1987; Mcllroy 2004).

It has become increasingly clear in recent years that complex animals evolved well before the base of the Cambrian. Indeed, recent studies consider two of the major Ediacaran clades (the Arboreomorpha and Rangeomorpha) as members of total group Eumetazoa (Dunn et al. 2021). Evidence for the existence of Ediacaran animals includes: preserved cnidarian muscles (Haootia; Liu et al. 2014, 2015) and surface locomotion trails (Liu et al. 2010) both from around 565Ma; the mollusk-like grazing trace (Kimberichnus; Ivantsov 2009) c. 550Ma; serial impressions of placozoan-type feeding (Dickinsonia, Epibaion; Ivantsov \& Malakhovskaya 2002; Sperling \& Vinther 2010) c. 550Ma; as well as bilaterian burrows (Parry et al. 2017) and ?annelid trails close to the basal Cambrian (Chen et al. 2018) both c. 542Ma. Debates around whether the Cambrian explosion of complex animal life had a short or long Ediacaran fuse (Brasier 2000; Zhu et al. 2017) have thus mostly converged on a consensus that there was a long Ediacaran pre-history to the Cambrian biotas. The issue of how and why complex animal life diverged so markedly during the Ediacaran-Cambrian transition is still a source of debate (Brasier 1979; Runnegar 1982; Seilacher 1997; Dzik 2005; Xiao \& Laflamme 2009; Erwin \& Tweedt 2012; Droser et al. 2017; Wood \& Erwin 2017; Wood et al. 2019).

Perhaps the most interesting questions around Ediacaran palaeobiology relate to first and last occurrences of taxa (e.g. Narbonne \& Gehling 2003; Liu et al. 2011; Liu et al. 2014; 
Matthews et al. 2020), but also the biotic transition from the Ediacaran into the Cambrian (Droser et al. 2017). With almost all first order evolutionary innovations (e.g. biomineralization, terrestrialization etc.) there is a period of time with equivocal evidence for the event prior to its universally accepted advent. This is likely usually due to localized innovation that is difficult to characterize, followed by rapid radiation/dispersal (e.g. Budd \& Jensen 2017). The record of the end of the Ediacaran and the Cambrian explosion of animal life include examples of Ediacaran survivors in Cambrian rocks (e.g. Swarpuntia Jensen et al. 1998; Hagadorn \& Waggoner 2000), and also evidence of putative Cambrian type trace fossils below the recognized Ediacaran Cambrian boundary (Gehling et al. 2001; Högström et al. 2013; Jensen et al. 2019; Jensen et al. 2000). It is to this latter transition, from the matground dominated Ediacaran to the macroscopically bioturbated Cambrian (McIlroy \& Logan 1999; Seilacher et al. 2005), that our attention is drawn herein.

\section{Microbially dominated seafloors at the dawn of animal life}

Matgrounds were common in late Proterozoic marine ecosystems, forming wherever there was a sufficiently low rate of sedimentation to allow organic matter to settle onto sediment surfaces. In the absence of surficial detritus-feeders and conveyor activity by bioturbators, the development of matgrounds developed largely unchecked for the majority of the Proterozoic history of microbial life (Walter 1977). The microbial consortia that made up Proterozoic and lowermost Palaeozoic matgrounds, the physical integrity of matgrounds, and their shear strength remain effectively unknown. It is presumed that in shallow water depositional settings there was a strong photosynthetic component and that matgrounds were dominantly algal in nature (e.g. Gehling 1999), but in deep marine settings the matgrounds likely also had a range of sulphur-oxidizing bacteria close to the sediment-water interface (McIlroy et al. 2005; Menon et al. 2017). Modern matgrounds are loci of large amounts of microbial biomass and microbial DOM production (Prieto-Barajas et al. 2018). In fine-grained sediments, the matground microbiota occludes pore throats with filaments, resulting in porewater dysoxia or even anoxia very close to the sedimentwater interface (Lawrence et al. 1994). The fine-grained sediment below the (macro)fossiliferous Ediacaran matgrounds of Avalonia was most commonly pelagite or hemipelagite, probably with relatively high amounts of porewater (Brasier et al. 2013; Harazim et al. 2013). The smothering of these matground surfaces by the growth of reclining organisms or fallen erect organisms commonly caused the preservation of negative impressions of even the delicate fronds of Ediacaran organisms (McIlroy et al. 2009; Fig. 1a).

One of the most distinctive aspects of the earliest Ediacaran soft-bodied macrobiotas is that-with few rare exceptions - they were immotile, and in many cases grew to very large sizes on matgrounds (Narbonne \& Gehling 2003; Liu et al. 2016; Taylor et al. 2021; Fig. 1b). Being immotile on a porous organic-rich seafloor potentially results in serious biogeochemical challenges in the form of hydrogen sulfide buildup below the body tissues (Ortega et al. 2008; Dufour \& McIlroy 2017a, b). If hydrogen sulfide accumulates unchecked next to the epithelium of an immotile recliner it would likely cause cell-death, meaning that soft-bodied Ediacaran organisms must have been able to modify the organism-substrate interface in a manner that detoxified, or otherwise mitigated, sulfide toxicity (McIlroy et al. 2021). Other strategies that animals employ to allow growth on sulfidic porewater substrates involve creation of an inert barrier between the sediment and the organism such as the holdfasts of Crinoids (Seilacher \& MacClintock 2005), the basipinacocytes of sponges (Dufour \& McIlroy 2017b), or the mucous burrow linings of burrowers that make permanent dwellings (e.g. cerianthid anemones, Frey 1970; Bromley 1996). The most common way for modern soft-bodied organisms to avoid sulfide toxicity is to either move on a regular basis (e.g. the placozoan Trichoplax initiates movement in response to sulfide concentrations (Loenarz et al. 2011) or to detoxify this hydrogen sulfide by pumping oxygen to the sediment interface, causing oxidation of sulfide to thiosulphate (cf. Dufour \& Felbeck 2003; Dufour \& Mcllroy 2017a; Fig. 1c). There are many common ectoand endo-symbioses between sulfur oxidizing bacteria and animals, particularly on high surface area, oxygen-rich, epithelia such as gills (Dufour 2005; Dubilier et al. 2008). 

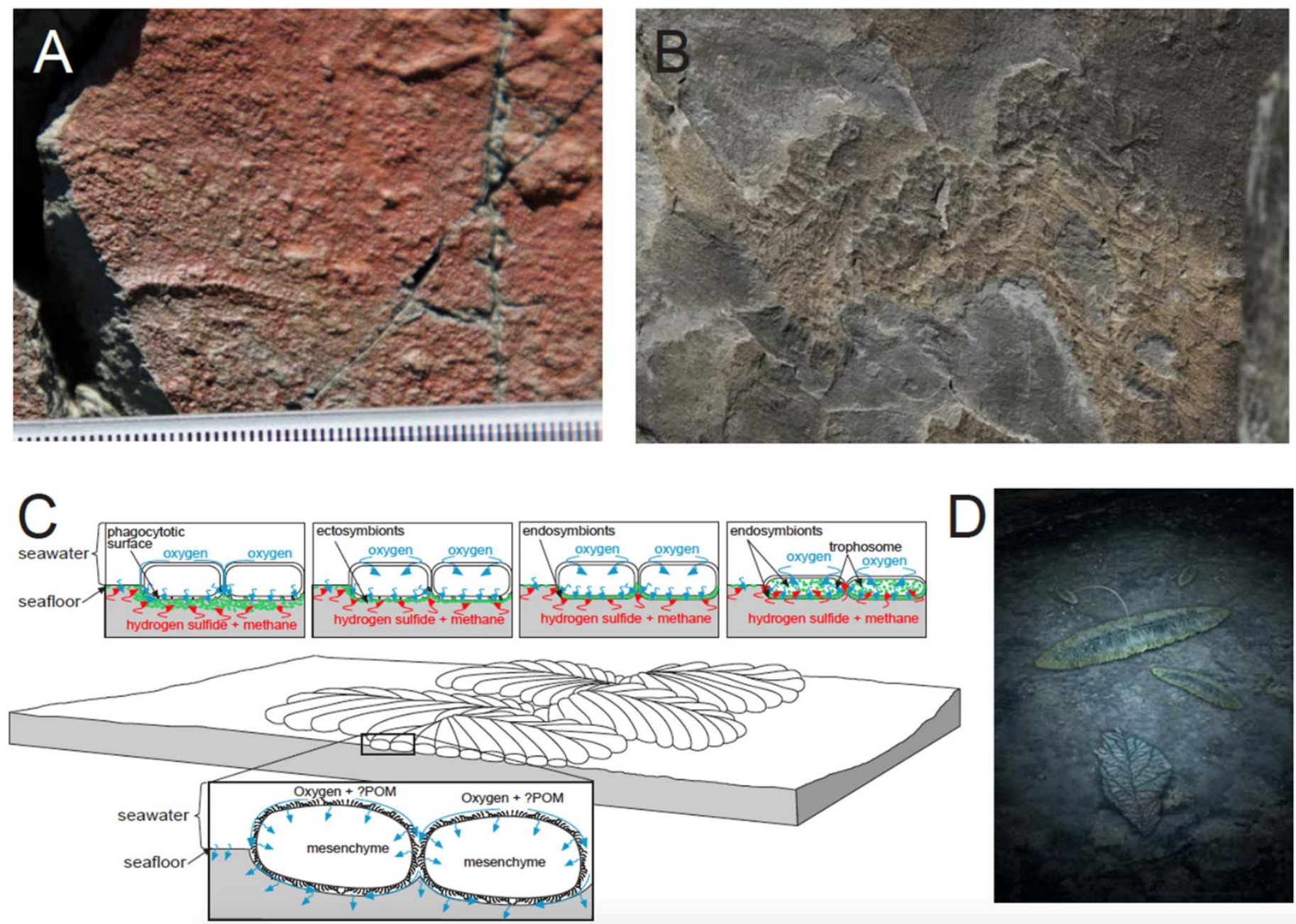

Figure 1. A) Long, narrow Ediacaran frond from Mistaken Point Ecological reserve, NL (scale bar in mm); B) Large reclining rangeomorph Ediacaran frond. aff. Bradgatia sp. from the MUN surface, Catalina Dome, NL; C) Diagrammatic reconstruction of a generic reclining rangeomorph detailing the ways that it might have interacted with the substrate. The lower surface is irrigated with seawater by ciliary action and diffusion. The supply of oxygen to the lower surface is considered to have increased microbial productivity. The top row of images show possible feeding modes with green circles showing the distribution of chemolithoautotrophic symbionts and arrows show diffusion of solutes. Furthest left is phagotrophy, next is ectosymbiosis, then endosymbiosis and furthest right is endosymbiosis with a trophosome (requiring diffusion of sulfide/methane into a thin organism) POM = Particulate Organic Matter. All of these methods of gaining nutrition would work for endobenthic graphoglyptids; D) reconstruction of the Ediacaran seafloor of Mistaken Point Formation.

The earliest examples of Ediacaran fossils include the epibenthic Rangeomorpha, some of which had fractal-like lower surfaces and lived reclined on the seafloor (Hawco et al. 2020; McIlroy et al. 2020, 2021; Fig. 1d). Some rangeomorphs actively displaced sediment during growth such that they grew slightly below the ambient sediment-water interface (Droser et al. 2014) and as such were likely adapted to exploit sedimentary biogeochemical gradients, especially the very large reclining organisms (e.g. Bradgatia (see Liu et al. 2016) and Gigarimaneta (Taylor et al. 2021)). Fractal-like morphologies in reclining organisms are most consistent with sedimentary nutrient exploitation via symbioses with lithoautotrophic bacteria, based around the metabolism of methane, hydrogen, and hydrogen sulfide in particular. In these symbioses, the rangeomorph probably provided oxygen to and gained nutriment from the symbionts that it hosted. It is most likely in these simple organisms that there was a mixture of symbiosis and phagocytosis on the lower surface of the organism, in the microbial productivity hotspot generated by the localized enhanced near-organism oxic zone (Dufour \& McIlroy 2017a; Fig. 1c).

Due to the low rate of diffusion of oxygen into the sediment porewater systems that underlay the ubiquitous Ediacaran seafloor matgrounds, the redox profile of Ediacaran sediments is likely to have been significantly condensed (Aller 1978, 1982, 1984, 1994; 
Mcllroy \& Logan 1999). As a result, very little of the particulate and dissolved organic matter in such sub-mat settings will have been subject to aerobic respiration (the greatest energy yield per unit of organic carbon metabolized, e.g. White 1983; Konhauser 2007), leading to a predominance of sulfate reduction and methanogenesis. However, should a reclining organism grow atop an established matground and pump oxygenated seawater to its lower surface, this would stimulate productivity of chemolithoautotrophic bacteria such as sulfur oxidizers (which could utilize reductants diffusing from the sub-mat sediment profile, e.g. $\mathrm{HS}^{-}, \mathrm{NH}_{4}{ }^{+}$, Fe (II); Blackburn \& Blackburn 1993) as well as methanotrophs (e.g. Petersen \& Dubilier 2009). Such stimulation of microbial productivity is likely to have constituted the basis for simple ectosymbiosis/phagotrophic nutrition for reclining macro-organisms (Mcllroy et al. 2020).

\section{The slow death of the Ediacaran-type matground biotope}

From their acme in the Proterozoic, matgrounds like stromatolites slowly declined, becoming increasingly marginalized in the lowermost Paleozoic (Walter \& Heys 1985). Paleozoic matground facies became increasingly associated with environments that were somewhat hostile to burrowing animals such as low TOC mud-belts in front of deltas (Harazim et al. 2013; Harazim \& Mcllroy 2015), whereas in the lowermost Cambrian matgrounds were common in normal marine settings such as the lower shoreface (Mcllroy \& Logan 1999). Evidence for matground facies in siliciclastic settings is commonly in the form of Microbially Induced Sedimentary Structures (MISS) such as lineated bedding planes of Arumberia, wrinkled surfaces such as Kinneya and elephant-skin textures (McIlroy \& Walter 1997; Pflüger 1999; McIlroy et al. 2005; Noffke 2000; Noffke et al. 2002; McMahon et al. 2021). These same textures commonly recur after mass extinction events until biotic recovery re-establishes ecosystem services in the benthic realm, including the all-important ecosystem engineering burrowing endobenthos (e.g. Sheehan \& Harris 2004; Herringshaw et al. 2010; Herringshaw \& Mcllroy 2013; Mata \& Bottjer 2009; Feng 2021).

The stresses on the matground biotope that dominated hiatal marine seafloors of the Proterozoic largely result from the effects of bioturbation, which seemingly started in the Ediacaran with the evolution of bilaterian burrowers (Parry et al. 2017) along with the grazing activity of metazoans (e.g. Ivantsov 2009; Seilacher \& Hagadorn 2010; Chen et al. 2018). This matground stress likely escalated with the evolution of larger bulk-sediment deposit feeders around the base of Cambrian Stage 2 (Herringshaw et al. 2017), becoming better established as bioturbators increasingly sought out surficial and buried organic rich substrates through the lower Palaeozoic (Fig. 2a Bell Island). Modern levels of bioturbation and distribution would likely have developed very quickly. 

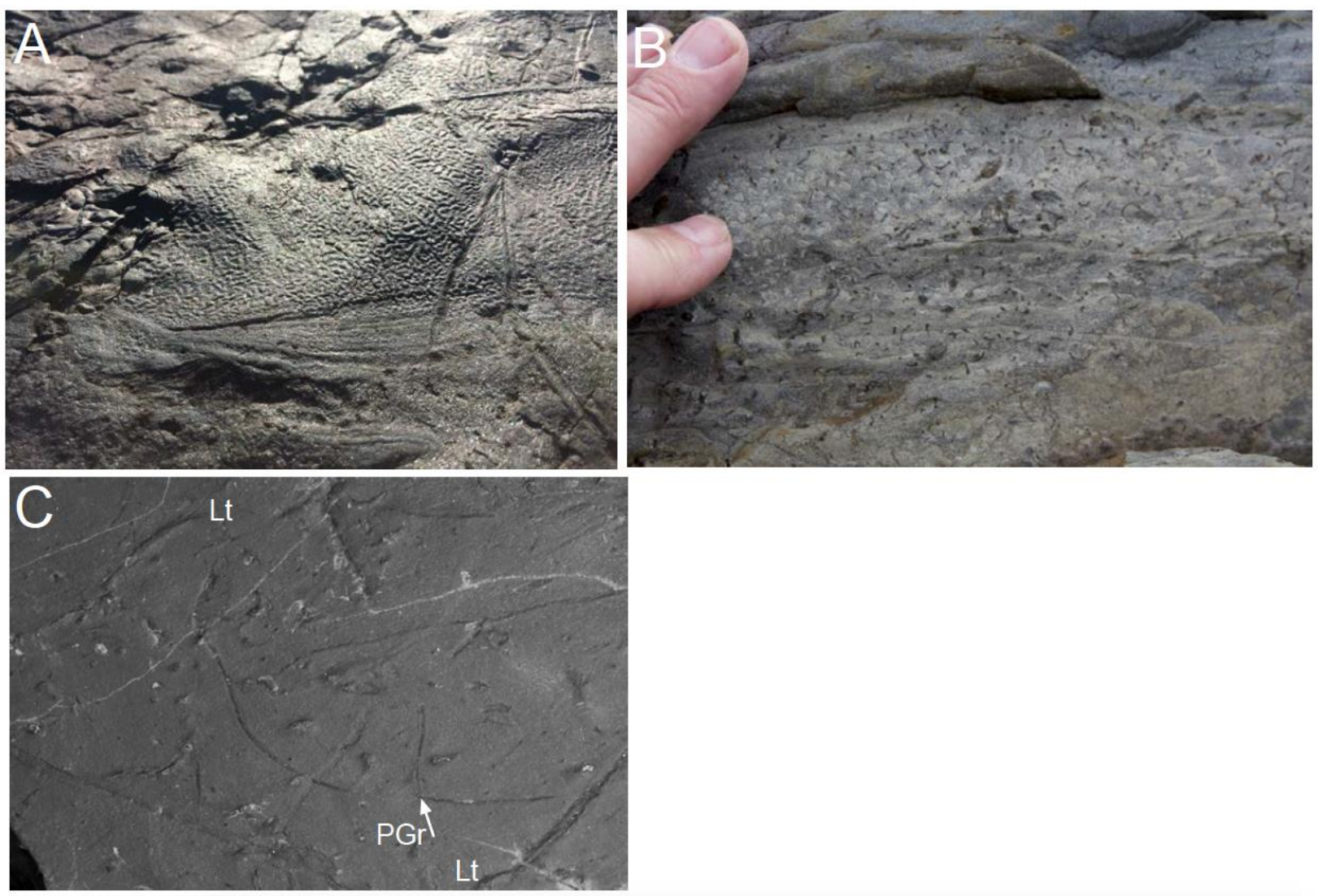

Figure 2. A) Microbial matground surface with wrinkled texture and abundant sediment mining trace fossils from the Ordovician of Bell Island, NL. Field of view c. $30 \mathrm{~cm}$; B) typical ichnofabric from the lower Fortunian of Fortune Head showing abundant curved, spiralling and branching pyritized burrows; C) bedding plane view of Lamonte trevallis burrows (Lt) and pyritized graphoglyptid burrows with $\mathrm{T}$ junction arrowed (field of view $15 \mathrm{~cm}$ ).

The presence of shallow burrows co-existing with elements of the soft bodied Ediacaran biota, while not entirely unexpected, does need to be considered with an open mind to alternative hypotheses. The morphologies of late Ediacaran burrows are commonly simple and narrow (Fig 2b). The most abundant trace in this period is the simple tubular burrow Lamonte trevallis (Meyer et al. 2014; Fig. 2c), which is interpreted as a member of an ichnoguild of under-mat miners (Seilacher 1999). Other regularly serial or branched burrows are commonly attributed to the treptichnid genera Treptichnus and Streptichnus (Jensen \& Runnegar 2005; Högström et al. 2013; Jensen et al. 2020). The importance of identifying Treptichnus alongside elements of the Ediacaran biota stems from the fact that the Treptichnus pedum (originally Phycodes pedum Seilacher 1966) ichnoassemblage zone is diagnostic of the base of the Cambrian, thereby creating an apparent stratigraphic conundrum, though in the present author's opinion, none of the purported Ediacaran Treptichnus closely resemble T. pedum. Which begs the question, to me at least, if they are not Treptichnus s.s. then what are they?

\section{The early putative burrowers of the Ediacaran-Cambrian Transition}

It is a seldom appreciated precept of ichnological (trace-fossil) studies that burrows do not generally betray the taxonomic affinities of the burrowing organism (Baucon et al. 2012), nor do they always represent a single life activity in most cases (e.g. Bromley 1996). A simple vertical burrow in a sand, for example, works just as well as a den for a predator or mucous net feeder as it does for a head-down deposit feeder (e.g. Herringshaw \& Mcllroy 2013). While most biologists would accept that as a truism, many palaeo-ichnologists are surprisingly content with making broad-brush assumptions of behaviour based on burrow morphology (Mcllroy 2008). 
The majority of the earliest fossil burrows do not show good evidence for deposit feeding activity, but rather are passively sediment-filled, diagenetic mineral-filled, or collapsed (refs; Herringshaw et al. 2017). In the type section for the Ediacaran-Cambrian boundary in southeastern Newfoundland, Canada, the open, passive filled burrows Treptichnus and Gyrolithes, dominate the ichnology of the Fortunian-aged Treptichnus pedum assemblage ichnozone (Crimes \& Anderson 1985; McIlroy \& Logan 1999; Herringshaw et al. 2017; Laing et al. 2018; Fig. 3). In the Fortunian stage of the lower Cambrian there are also abundant surface traces including arthropod burrows and surficial grazers/bulldozers (Crimes \& Anderson 1985; Narbonne et al. 1987), but it is not until slightly higher in the lower Cambrian (Cambrian Stage 2) that there is unequivocal evidence of bulk sediment deposit feeding activity (Herringshaw et al. 2017; McIlroy \& Brasier 2017).
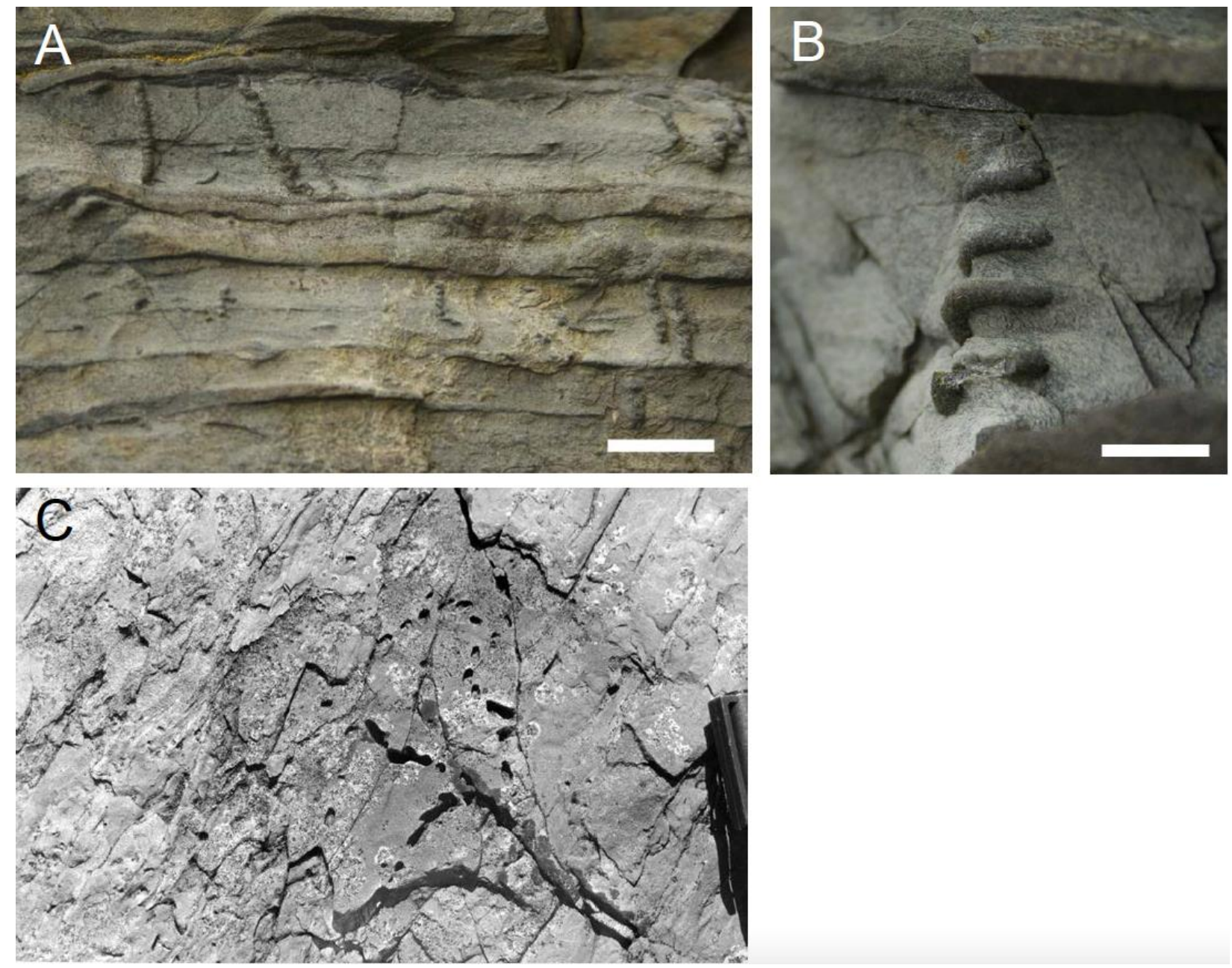

Figure 3. Tubular open "burrows" from the Fortunian of Fortune Head NL showing spiralling morphologies of: A) Gyrolithes gyratus; and B) G. scintillus with pyrite rich silty sandstone fill. C) shows the bedding plane view of a monopodially branching Treptichnus pedum in which the pyritic fill has weathered away showing the mold of the burrow, the space that would have been occupied in life. Whether these structures were burrows sensu stricto or casts of the exterior of spiralling or branching organisms remains to be determined.

The ichnogenus Treptichnus (sensu stricto) was created for fossilized burrows (Miller 1889) and has subsequently been applied to a range of marine trace fossils from deep marine turbidite successions throughout the Phanerozoic, as well as shallow marine trace fossils of the Palaeozoic and burrows of modern insect larvae (Muñiz-Guinea et al. 2014). The generic diagnoses of the similarly branching burrows of Trichophycus and Phycodes include the formation of spreite by serial bulk sediment deposit feeding and direct evidence of movement in the form of bioglyphs; fecal pellets are known from Cambrian Stage 2 (Jensen 1997; Orłowski \& Żylińska 1996; Fig. 4). Both Trichophycus and Phycodes have Treptichnus-like biserial and uniserial branching, which is almost certainly an example of 
convergent behavioural evolution for effective sediment exploration and exploitation using sympodial/feather stitch branching (Babcock et al. 2014; Mcllroy \& Brasier 2017; Buatois 2018).
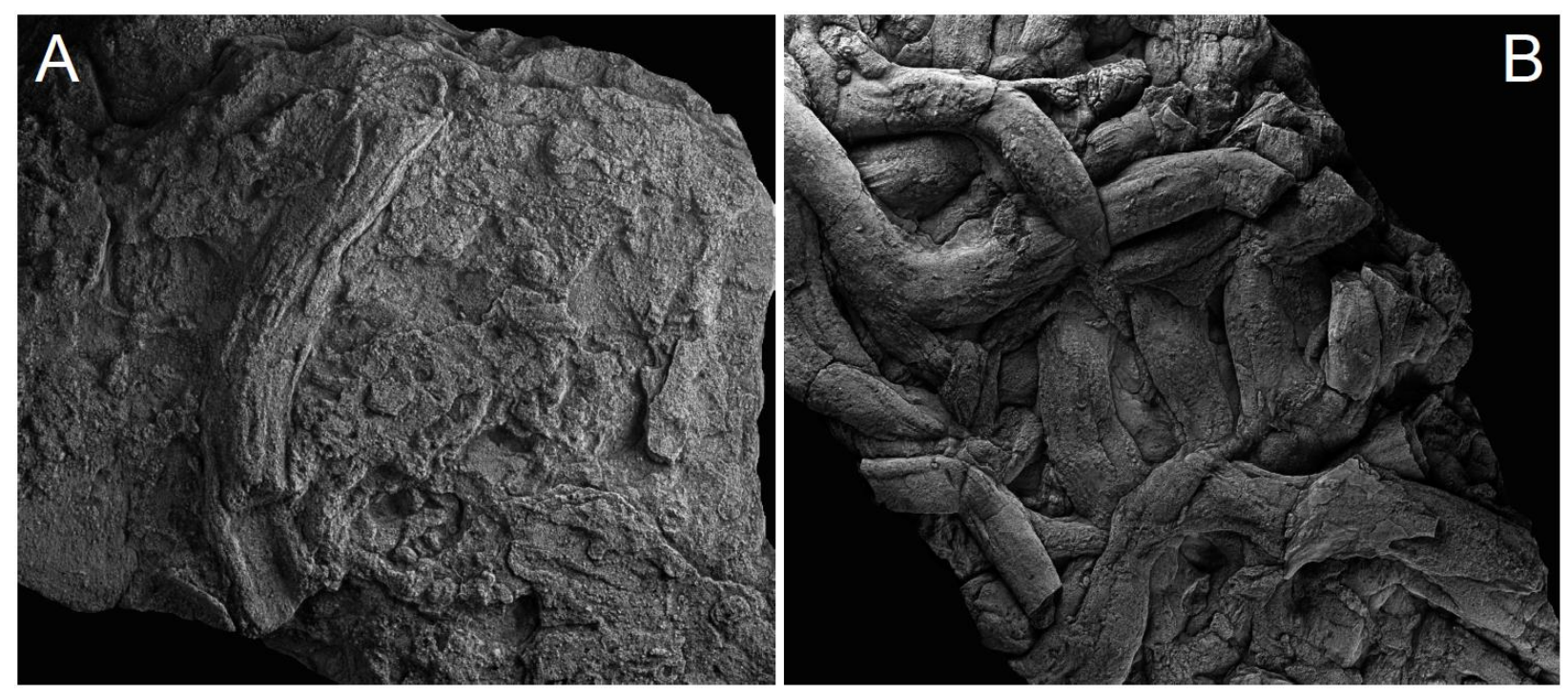

Figure 4. Segments of Trichophycus ispp. from the lower Cambrian Arumbera Sandstone of central Australia showing the stacked spreite (A) and scratch marks (B) that distinguish the genus from Treptichnus. Field of view A is $3 \mathrm{~cm}, \mathrm{~B}$ is $6 \mathrm{~cm}$.

While the ichnotaxonomic minutiae have been explored in detail, the question that seems not to have been asked is: what evidence do we have for the behaviour represented by the lowermost Cambrian marine treptichnids? We know that organisms have been able to exploit sub-seafloor settings by sediment displacive growth since the Ediacaran (Droser et al. 2014), so the question remains "Do we even know if the earliest endogenic structures were trace fossils sensu stricto and not just external molds of the first sediment displacive endobenthos?" I would posit that we do not.

If we are to open ourselves to the possibility of sediment displacive growth (sensu Droser $e$ t al. 2014) persisting beyond the Ediacaran, then there are a wide range of lower Cambrian burrow-like structures that are always passively filled with sediment or collapse (i.e. not backfilled by the trace maker) that could be reinvestigated. In this case rather than being burrows we could think of them as external molds.

Note that this is not the same as the approach to Treptichnus pedum by Dzik (2005) who conflated biotaxa and ichnotaxa (creating a priapulid genus Manycodes), even though the two do not complete under the ICZN. Manycodes has not been accepted as being synonymous with Treptichnus, though the Scalidophora are considered a likely trace-makers of Treptichnus- and Trichophycus-like burrows both modern and ancient (Kesidis et al. 2019).

\section{What are the Graphoglyptida if not the Rangeomorpha persevering?}

One of the remarkable things about the "trace fossil" record of the shallow marine matground-rich facies of the lowermost Cambrian is that there are numerous narrow, geometric graphoglyptids (sensu Fuchs 1895; Seilacher 1977). Graphoglyptids are primarily known from deep marine depositional settings (Seilacher 1962; Miller 1991; Uchman 2004; though see Fürsich et al. 2007; Olivero et al. 2010) from the Ordovician onwards and having a major radiation in the Cretaceous (Uchman 2004), perhaps coincident with the expansion of deciduous trees. The affinities of the Graphoglyptida are contentious, and even though some examples are known from modern seafloors, no trace-maker has yet been identified (Rona et al. 2009).

Recent work has divided the Graphoglyptida into three topological groups (Fan et al. 2018): 1) "line graphoglyptids" (mostly meanders and spirals) which are common in the 
Fortunian lower Cambrian worldwide (Fig. 5a, b); 2) "tree-form (mainly sympodiallybranching) graphoglyptids" (including Treptichnus; Uchman et al. 1998) which are locally common in lower shoreface settings (Fig. 5c, d); and 3) "net-type graphoglyptids" that are generally rare except in tempestite and prodelta turbidite deposits (e.g. Crimes \& Anderson 1985; McIlroy et al. 1997; Mcllroy \& Brasier 2017; Fig. 5e, f).

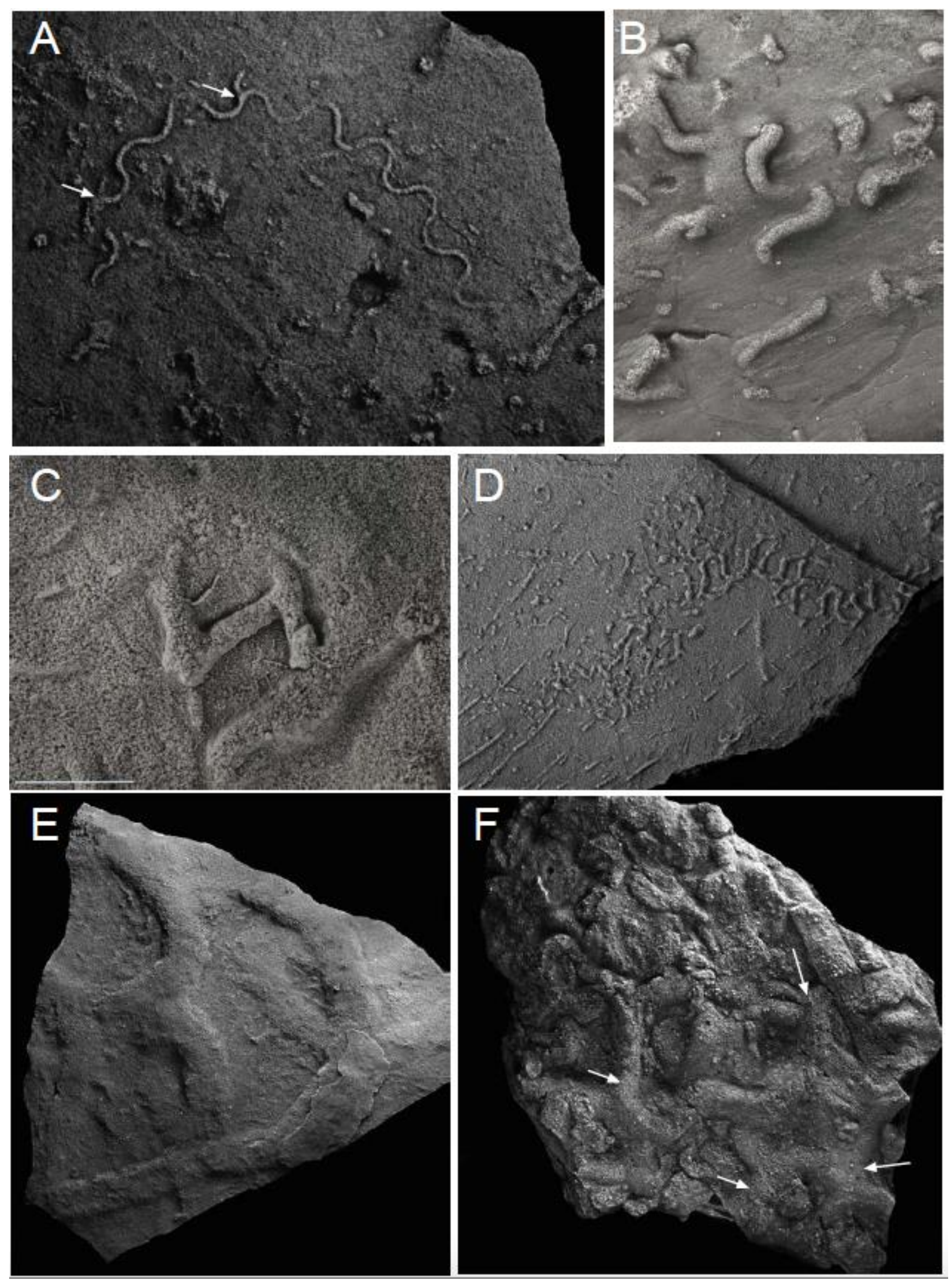


Figure 5. Graphoglyptid morphologies: A, B are line graphoglyptids (A Helminthoida though note the branching from the Cambrian Arumbera Sandstone Australia; B is Helicolithus from the latest Ediacaran of Tanafjord, Norway); C-D are branching graphoglyptids. (B is Belorhaphe from the late Ediacaran of Tanafjord, Norway, D is cf. Paleomeandron from the Cambrian Arumbera Sandstone); E-F are net graphoglyptids (E is Squamodictyon from the Arumbera Sandstone, Australia and F is Paleodictyon also from the Arumbera Sandstone).

Most authors have considered the mode of life of the graphoglyptid-making organisms to include a combination of: 1) intensive [near]surficial bulk-sediment detritus feeding in meanders and spirals (Seilacher 1977; Fan et al. 2018); and 2) the creation of open sub-surface branching burrows and networks that were maintained for the purpose of "farming" microbes on the burrow wall (Seilacher 1977).

\subsection{The early Vermiform/Line Graphoglyptids}

In the Cambrian, hiatal matground facies prior to the onset of deep deposit feeding activity is likely to have been associated with surficially-concentrated nutrients similar to the distribution of food on the deep basin floors exploited by modern systematic (meandering/spiraling) deposit feeders (e.g. Ekdale 1980). The similar trace fossil assemblage is perhaps to be expected.

That the surficial matground biotope was host to some of the earliest Ediacaran endogenic structures (e.g. Lamonte trevallis) is to be expected (Gingras et al. 2011). The ability of the organisms to penetrate matground textures is a most surprising and fundamental innovation, potentially opening up the sub-matground porewater systems to a second phase of microbial oxidation of buried organic matter. Since backfill is yet to be demonstrated in this under-mat-miner guild, it should also be considered that the open tubular structures with their high surface area to volume ratio might have been suitable for cilial bioirrigation by a very simple immotile animal living in the sediment. Such a mode of life would be particularly effective if the Lamonte-making organism had symbionts as did some of the rangeomorphs.

Other similar, open, unbranched features described as burrows are common in the latest Ediacaran and lower Cambrian. Several distinctive spiraled/sinuous taxa of uniform diameter without backfill are known from within meters of the Ediacaran-Cambrian boundary, including the vertically spiraled Gyrolithes scintillus and G. gyrates (Fig. 3) and horizontally spiraled Helicolithus (Banks 1970; Herringshaw et al. 2017; Mcllroy \& Brasier 2017; Laing et al. 2018; Fig. 5a), Streptichnus (Jensen \& Runnegar 2005), and some ?Treptichnus (Jensen et al. 2020). All of these taxa are considered to have been maintained such that they were constantly open to seawater and are commonly partly pyritized. That the burrows are commonly pyritized is suggestive of the presence of sulfur oxidizing bacteria that would be predicted by the ciliary irrigating mode of life of the symbiotic/phagocytotic Rangeomorpha proposed by Dufour \& McIlroy (2017a).

Previous work has noted the potential for bacterial farming in Gyrolithes (Laing et al. 2018), presumably via bioirrigation (Herringshaw et al. 2010), but did not consider a rangeomorph-like chemosymbiotic mode of life. The bacterial farming mode of life seems to rely on some form of burrow wall grazing for which there is to date no convincing evidence. Younger occurrences of Gyrolithes are commonly attributed to conventional dwelling or deposit feeding burrows of bilaterian taxa from various "worms", arthropods and even vertebrates (e.g. Laing et al. 2018). Modern Helicolithus-like burrows are known to be formed in sulfidic marine sediments by the deposit feeding enteropneust Saccoglossus (Gingras et al. 2010).

If the paradigm for a rangeomorph-like symbiotic lifestyle (McIlroy et al. 2021) can be extended to unbranched, high surface area-volume ratio burrows without evidence of burrowing action/feeding, then the atypical nature of the earliest trace-fossil biotas and their overlap with the Ediacaran biotas might be explainable.

\subsection{The Tree-like Graphoglyptids of the E-C boundary}

Recognition of the tree-like graphoglyptids in bedding plane expression is commonly facilitated by the presence of sharp, commonly high angle branches - even $90^{\circ}$ branching. 
That in itself is unremarkable (e.g. Frey \& Bromley 1985), but to have $90^{\circ}$ branching without corner rounding (see Treptichnus in Baucon et al. 2014, their fig. 6) is unusual/unknown in burrows that are constantly patrolled by the trace-maker. A large number of trace fossils fall into this category; many of them are very beautiful, consisting of high angle branching in complex shapes, often forming meanders and almost never self-crossing. Most Phanerozoic examples of the tree-like graphoglyptids have very long chains of selfsimilar elements in a single meandering burrow (e.g. Uchman 2004). Cambrian examples attributed to the same ichnotaxa tend to be short and slightly atypically irregular (McIlroy \& Brasier 2017; Fig. 5c, d).

In the farming model for graphoglyptid palaeobiology (Seilacher 1977), the endobenthic organism is inferred to have either actively or passively irrigated the burrow, thereby providing a large surface area supplied with oxygenated seawater upon which a microbiota could be cultured.

The most common tree-like, branching open burrow in the Cambrian is Treptichnus pedum, which may have alternated between biserial and uniserial sympodial branching. The feather-stitch biserial branching produces effectively straight burrows, with terminal openings at the end of each blind ended branch (Fig. 6a). The length of branches and their angle can vary considerably, affecting spacing between branching (Fig. 6b). The same burrows can curve by undergoing uniserial sympodial branching (Fig. 6c) while avoiding self-crossing, perhaps in response of physico-chemical seafloor gradients.
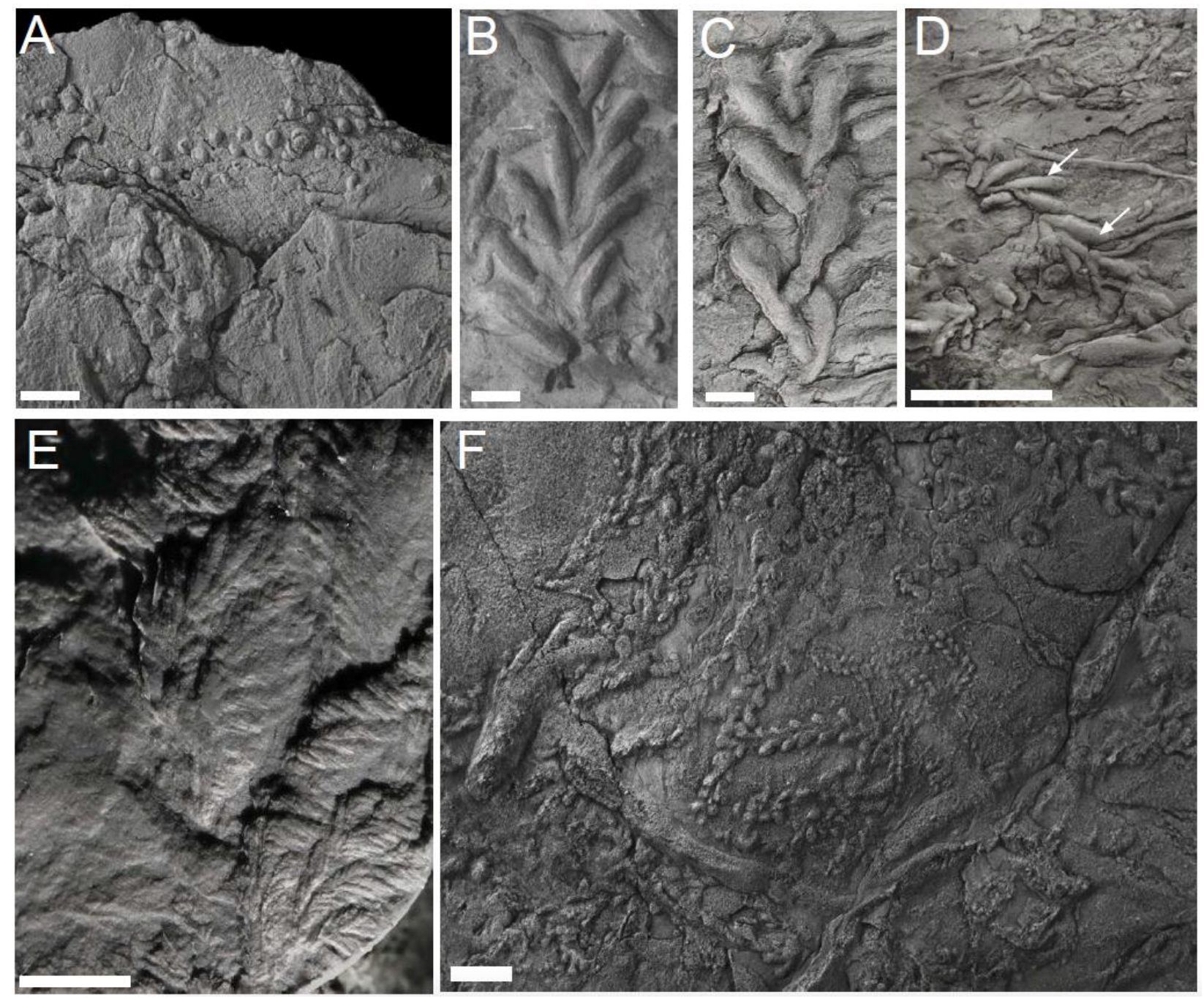

Figure 6. A-D Treptichnus pedum showing a range of branching types. All preserved as open burrow fills from the Fortunian of Tanafjord, Norway. D shows both uniserial and biserial monopodial branching. E is a small portion of aff. Bradgatia showing Treptichnus like branching. F Treptichnus lublinensis showing meandering habit and very rangeomorph-like branching. Scale bars $1 \mathrm{~cm}$ except $D$, which is $5 \mathrm{~cm}$. 
The epibenthic rangeomorph Bradgatia undergoes similar branching in search of nutrients (Fig. 6d) and likely had an oxygen-capturing upper surface and a ciliated lower surface providing fresh supplies of seawater to its episymbionts. The other species of Treptichnus that is only known from the lower Cambrian is the very shallow tier rangeomorph-like Treptichnus lublinensis, which would not look out of place in some of the iconic deep marine Ediacaran biotas (McIlroy et al. 2021; Fig. 6e). Additionally, zig-zagged open burrows attributed to Belorhaphe sp. (Fig. 5c) from the latest Ediacaran of Norway (McIlroy \& Brasier 2017) are much like Treptichus except for the branching position and small size. This not to say that the treptichnids and forms like Belorhaphe were indeed rangeomorphs per-se, just that they may have had a rather rangeomorph-like mode of life and growth (albeit endobenthically rather than epibenthically) and were not necessarily deposit feeders as is commonly stated but may have had a sediment-displacive mode of life. As we strive to understand these purported trace fossils, we need to bear in mind the possibility that they could be external molds rather than burrows.

\subsection{The Net-like Graphoglyptida}

The net-like Graphoglyptida are some of the most complex burrow systems in marine depositional settings. If they were to be created by burrowing, their excavation would require complex "programming" (Seilacher 1977) to evolve at or before the EdiacaranCambrian boundary since the net-like graphoglyptids are known from the latest Ediacaran (described as Multina or Olenichnus; Fedonkin 1985; Parry et al. 2017; McIlroy \& Brasier 2017; Fig. 7).
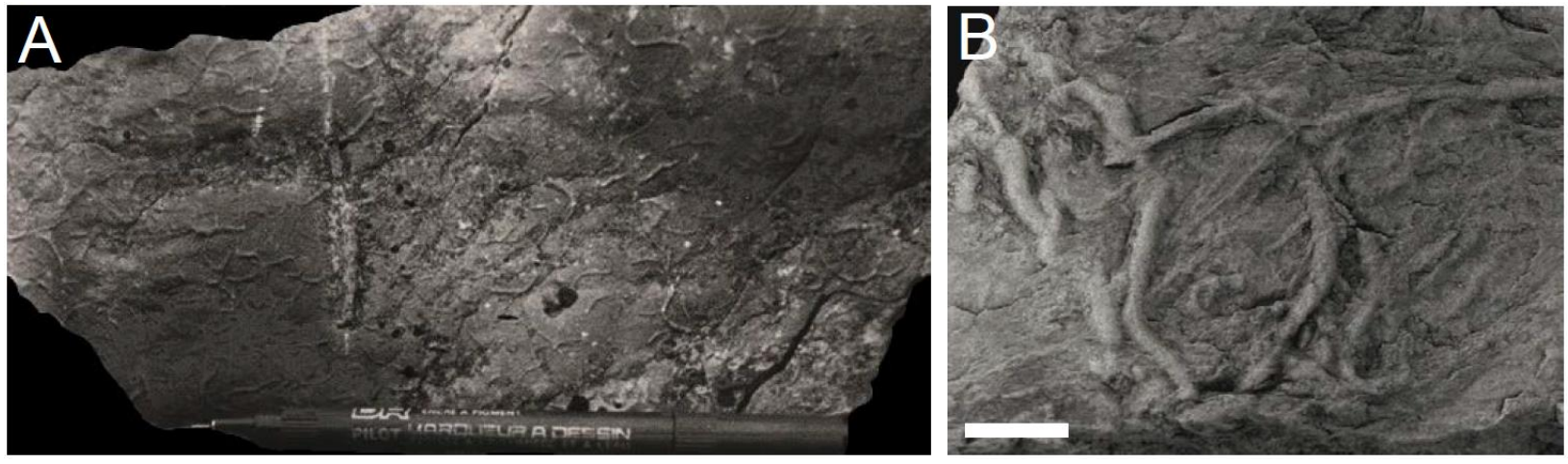

Figure 7. Net-type graphoglyptids from the Ediacaran (A) Multina and Fortunian (B) Paleodictyon of Tanafjord. Some of the supposedly most complicated marine trace fossils amidst the earliest record of endobenthic activity. Scale bar $1 \mathrm{~cm}$.

Modern soft-sediment cores have occasionally recovered shallow-tier polygonal xenophyophore-like protistan organisms (Swinbanks 1982) comparable to partial Palaeodictyon. At the same time, however, it is possible for simple organisms such as nematodes and foraminifera to make multi-tiered network burrows comparable to Multina sp. (Severin et al. 1982; Balinski et al. 2013). Some of the network-like morphology of Multina and Olenichnus have sharp (unrounded) angles at the branching points of the Graphoglyptida. That lack of corner rounding is common to all Palaeodictyon and, for this author at least, is very suggestive of branched growth evincing preservation of external molds of an organism rather than being a constantly patrolled burrow. Corner rounding is common in all long trace makers, e.g. worms and some arthropods. Some authors have argued that sharp corners could be maintained in networks if burrowed by a trace-maker that is about as long as the burrow is wide (Fan et al. 2018).

\section{Conclusion or "What if....?"}

The ideas outlined above constitute testable hypotheses that admittedly ask very difficult questions of the rock specimens we have to work with, but should not be discarded in preference for conventional interpretations without careful consideration. 
The questions around the demise of the Ediacaran biotas and the diversification of animals in the lower Cambrian are first order palaeontological questions. Whether the graphoglyptids function as microbe farms that were patrolled, irrigated and browsed upon by a short-bodied active burrower; or whether they are the external molds of a simple pre-placozoan-grade rangeomorph-like organism that grew in or through the sediment is also key.

If we could know unequivocally what the enigmatic open burrow-like structures in the lowermost Cambrian are, we might become a step closer to understanding either the persistence or otherwise of the chemosymbiotic Rangeomorpha, or better appreciate the palaeobiology of the earliest burrows. Either way, it is considered here that they might make a poor choice for delineating the base of the Phanerozoic. The abundant traces of arthropods might be preferable for their lack of ambiguity if nothing else.

The fossil record of the dawn of animal life is full of hints and contradictory evidence, provincialism and incomplete datasets. The questions around the affinities of the Ediacaran biota and the appropriate choice of marker for the Ediacaran boundary are still far from resolved. There is much yet to do, and the hypotheses generated by asking the awkward question 'What if...?' are more likely to provide novel answers than not asking.

Acknowledgments: Apologies to Marvel Comics for the bastardization of the wonderful line "What is grief if not love persevering" from WandaVision. It was made for palaeontology/evolution.

\section{References:}

Aller, R.C. 1978. Experimental studies of changes produced by deposit feeders on pore water, sediment and overlying water chemistry. American Journal of Science 278:1185-1234.

Aller, R.C. 1982. The effects of macrobenthos on chemical properties of marine sediments and overlying water. In: McCall, P.L., \& Tevesz, M.J.S. (eds), Animal-Sediment Relations: Plenum, New York, p. 53-102.

Aller, R.C. 1984. The importance of relict burrow structure and burrow irrigation in controlling sedimentary solute distributions. Geochimica et Cosmochimica Acta 48:1929-1934.

Aller, R.C. 1994. Bioturbation and remineralization of sedimentary organic matter: Effects of redox oscillation: Chemical Geology 114:331-345.

Babcock, L.E., Peng, S., Zhu, M., Xiao, S. \& Ahlberg, P. 2014. Proposed reassessment of the Cambrian GSSP. Journal of African Earth Sciences 98: $3-10$.

Baliński, A., Sun, Y., and Dzik, J. 2013. Marine nematodes from 470 million years old Early Ordovician rocks in China. Nematology 15:567-574.

Banks, N.L. 1970. Trace fossils from the late Precambrian and Lower Cambrian of Finnmark, Norway. In: Crimes, T.P. \& Harper, J.C. (eds) Trace Fossils. Geological Journal 3:19-34.

Baucon, A., Bordy, E., Brustur, T., Buatois, L., Cunningham, T., De, C., Duffin, C., Gaillard, C., Hu, B., Hu, L., Jensen, S., Knaust, D., Lockley, M., Lowe, P., Mayor, A., Mayoral, E., Neto de Carvalho, C., Pollard, J., Rindsberg, A. K., Seike, K., Song, H., Turner, S., Uchman, U., Wang, Y., Gong, Y., Zhang, W., and Zhang, L. 2012. A history of ideas in ichnology. In: Knaust, D. \& Bromley, R. G. (eds), Trace Fossils as Indicators of Sedimentary Environments. Amsterdam, Elsevier, Developments in Sedimentology, 64: 3-43.

Baucon, A., Ronchi, A., Felletti, F., and Neto De Carvalho, C. 2014. Evolution of Crustaceans at the edge of the end-Permian crisis: Ichnonetwork analysis of the fluvial succession of Nurra (Permian-Triassic, Sardinia, Italy). Palaeogeography, Palaeoclimatology, Palaeoecology 410: 74 103. DOI:10.1016/j.palaeo.2014.05.034

Blackburn, N.D. and Blackburn, T.H. 1993. A reaction diffusion model of C-N-S-O species in a stratified sediment. FEMS Microbiology Ecology 102:207-215.

Brasier, M.D. 1992. Introduction: background to the Cambrian explosion. Journal of the Geological Society, London, 149:585-587. DOI:10.1144/ gsjgs.149.4.0585.

Brasier, M.D. 1979. The Cambrian radiation event. In: House, M.R. (ed), The Origin of Major Invertebrate Groups. Academic Press, London, 103-159.

Brasier, M.D. 2000. The Cambrian explosion and the slow burning fuse. Science Progress 83:77-92.

Brasier, M.D., Liu, A.G., Menon, L., Matthews, J.J., McIlroy, D., and Wacey, D. 2013. Explaining the exceptional preservation of Ediacaran rangeomorphs from Spaniard's Bay, Newfoundland: A hydraulic model. Precambrian Research 231:122-135. DOI:10.1016/j.precamres.2013.03.013.

Bromley, R.G. 1996. Trace Fossils. Biology, Taphonomy and Applications, 2nd ed. xvi + 361 pp. London, Glasgow, Weinheim, New York, Tokyo, Melbourne, Madras: Chapman \& Hall.

Buatois, L.A. 2018. Treptichnus pedum and the Ediacaran-Cambrian boundary: significance and caveats. Geological Magazine 155: 174-180. DOI: $1017 /$ S0016746817000656

Budd, G.E. and Jensen, S. 2017. The origin of the animals and a 'Savannah' hypothesis for early bilaterian evolution. Biological Reviews 92:446473.

Chen, Z., Chen, X., Zhou, C., Yuan, X., and Xiao, S. 2018. Late Ediacaran trackways produced by bilaterian animals with paired appendages. Science Advances 4: DOI: 10.1126/sciadv.aao6691

Crimes, T.P., and Anderson, M.M. 1985. Trace fossils from late Precambrian-early Cambrian strata of southeastern Newfoundland (Canada). Temporal and environmental implications: Journal of Paleontology 59:310-343.

Droser, M.L., Gehling, J.G., Dzaugis, M.E., Kennedy, M.J., Rice, D., and Allen, N.F. 2014. A new Ediacaran fossil with a novel sediment displacive life habit. Journal of Paleontology 88:145-151. DOI:10.1666/12-158.

Droser, M.L., Tarhan, L.G., and Gehling, J.G. 2017. The rise of animals in a changing environment: global ecological innovation in the late Ediacaran. Annual Review of Earth and Planetary Sciences 45:593-617. 
Dubilier, N., Bergin, C., and Lott, C. 2008. Symbiotic diversity in marine animals: the art of harnessing chemosynthesis. National Reviews Microbiology 6:725-740. DOI:10.1038/nrmicro1992.

Dufour, S.C. 2005. Gill anatomy and the evolution of symbiosis in the bivalve family Thyasiridae. Biol. Bull. 208, 200-212. https://doi.org/10.2307/3593152.

Dufour, S.C., and McIlroy, D. 2017a. Ediacaran pre-placozoan diploblasts in the Avalonian biota: the role of chemosynthesis in the evolution of early animal life. In: Brasier, A.T., McIlroy, D., \& McLoughlin, N. (eds), Earth System Evolution and Early Life: A Celebration of the Work of Martin Brasier. Geological Society, London, Special Publications, vol. 448:211-221. https://doi.org/10.1144/SP448.5.

Dufour, S.C., and McIlroy, D. 2017b. An Ediacaran pre-placozoan alternative to the pre- sponge route towards the Cambrian explosion of animal life: a comment on Cavalier- Smith 2017. Philosophical Transactions of the Royal Society B 373. DOI:10.1098/rstb.2017.0148.

Dufour S.C., and Felbeck, H. 2003. Sulphide mining by the superextensile foot of symbiotic thyasirid bivalves. Nature 426:65-67

Dunn F.S., Liu, A.G., Grazhdankin, D.V., Vixseboxse, P., Flannery-Sutherland, J., Green, E., Harris, S., Wilby, P.R. \& Donoghue, P.C.J. 2021. The developmental biology of Charnia and the eumetazoan affinity of the Ediacaran rangeomorphs. Sciences Advances 7, eabe0291,

Ekdale, A.A. 1980. Graphoglyptid burrows in modern deep sea sediment. Science 207:304-306.

Flannery-Sutherland, J., Green, E., Harris, S., Wilby, P.R., Donoghue, P.C.J. The developmental biology of Charnia and the eumetazoan affinity of the Ediacaran rangeomorphs. Science Advances 7: eabe0291. DOI:10.1126/sciadv.abe0291.

Dzik, J. 2005. Behavioral and anatomical unity of the earliest burrowing animals and the cause of the 'Cambrian explosion'. Paleobiology 31:503521.

Erwin, D.H., and Tweedt, S.M. 2012. Ecological drivers of the Ediacaran-Cambrian diversification of Metazoa. Evolutionary Ecology 26:417433.

Fan, R., Gong, Y., and Uchman, A. 2018. Topological analysis of graphoglyptid trace fossils, a study of macrobenthic solitary and collective animal behaviors in the deep-sea environment. Paleobiology 44:306-325. doi:10.1017/pab.2018.1.

Fedonkin, M.A. 1985. Paleoikhnologiya vendskikh Metazoa. [Paleoichnology of the Vendian Metazoa.] In: Sokolov, B.5. \& Ivanovskij, A.B. (eds): Vendskaya Sistema 1. Paleontologiya 1:12-117. Nauka, Mo skva.

Feng, X. 2021. Reassessing Early Triassic wrinkle structures from moderate-high latitudes: An updated interpretation of metazoan colonization in matground ecosystems after the Permian-Triassic mass extinction. Global and Planetary Change 205: DOI:10.1016/j.gloplacha.2021.103590.

Frey, R.W. 1970. The Lebensspuren of some common marine invertebrates near Beaufort, North Carolina. II. Anemone Burrows. Journal of Paleontology 44:308-311.

Frey, R.W., and Bromley, R.G. 1985. Ichnology of American chalks: the Selma Group (Upper Cretaceous), western Alabama. Canadian Journal of Earth Sciences 22: 801-828.

Fuchs, T. 1895. Studien über Fucoiden und Hieroglyphen. Denkshriften der Kaiserlichen Akademie der Wissenshaften, Wien, Matematisch Naturwissenschaftliche Klasse 62:369-448.

Fürsich, F.T., Taheri, J., and Wilmsen, M. 2007. New occurrences of the trace fossil Paleodictyon in shallow marine environments: examples from the Triassic-Jurassic of Iran. Palaios 22:408-416.

Gehling, J.G. 1999. Microbial mats in terminal Proterozoic siliciclastic Ediacaran death masks. Palaios 14:40-57.

Gehling, J.G., Jensen, S., Droser, M.L., Myrow, P.M. and Narbonne, G.M. 2001. Burrowing below the basal Cambrian GSSP, Fortune Head, Newfoundland. Geological Magazine 138:213-218.

Geyer, G. and Landing, A. 2017. The Precambrian-Phanerozoic and Ediacaran - Cambrian boundary: a historic approach to a dilemma. In: Brasier, A.T., McIlroy, D. \& McLoughlin, N. (eds), Earth System Evolution and Early Life: A Celebration of the Work of Martin Brasier. Geological Society, London, Special Publications, 448:311-349. DOI:10.1144/SP448.10.

Gingras, M.K., Dashtgard, S.E., MacEachern, J.A., and Pemberton, S.G. 2010. Biology of shallow marine ichnology: a modern perspective. Aquatic Biology 2:255-268. DOI: 10.3354/ab00055

Gingras, M., Hagadorn, J.W., Seilacher, A., Lalonde, S.V., Pecoits, E., Petrash, D., and Konhauser, K.O. 2011. Possible evolution of mobile animals in association with microbial mats. Nature Geosciene 4:372-375. DOI:10.1038/ngeo1142

Harazim D., Callow, R.H.T., and McIlroy D. 2013. Microbial mats implicated in the generation of intrastratal shrinkage ('synaeresis') cracks. Sedimentology 60:1621-1638.

Harazim, D. and McIlroy, D. 2015. Mud-rich density-driven flows along an early Ordovician storm-dominated shoreline: Implications for shallowmarine facies models. Journal of Sedimentary Research 85:509-528. DOI:10.2110/jsr.2015.38.

Hagadorn, J.W. and Waggoner, B. 2000. Ediacaran fossils from the southwestern Great Basin, United States. Journal of Paleontology 74: 349359.

Hawco, J., Kenchington, C.G., Taylor, R.S., and McIlroy, D. 2020. A multivariate statistical analysis of the Ediacaran rangeomorph taxa Beothukis and Culmofrons. PALAIOS 35:495-511.

Herringshaw, L.G., Sherwood, O.A. and McIlroy, D. 2010. Ecosystem engineering by bioturbating polychaetes in event bed microcosms. Palaios 25:46-58

Herringshaw, L.G. and McIlroy, D. 2013. Bioinfiltration: irrigation-driven transport of clay particles through bioturbated sediments. Journal of Sedimentary Research 83:443-450.

Herringshaw, L.G., Callow, R.H.T., and McIlroy, D. 2017. Engineering the Cambrian explosion: the earliest bioturbators as ecosystem engineers. In: Brasier, A.T., McIlroy, D., \& McLoughlin, N. (eds), Earth System Evolution and Early Life: A Celebration of the Work of Martin Brasier. Geological Society, London, Special Publications, vol. 448:369-382. DOI: 10.1144/SP448.18.

Högström, A.E., Jensen, S., Palacios, T., and Ebbestad, J.O.R. 2013. New information on the Ediacaran-Cambrian transition in the Vestertana Group, Finnmark, northern Norway, from trace fossils and organic-walled microfossils. Norwegian Journal of Geology 93:95-106.

Ivantsov, A.Y. 2009. New reconstruction of Kimberella, problematic Vendian metazoan. Paleontological Journal 43:601-611. DOI:10.1134/S003103010906001X.

Ivantsov, A.Y. and Malakhovskaya, Y.A. 2002. Giant traces of Vendian animals. Doklady Earth Sciences 385:618-622.

Jensen, S. 1997. Trace fossils from the Lower Cambrian Mickwitzia sandstone, south-central Sweden. Fossils and Strata 42:1-112.

Jensen, S, Gehling, J.G., and Droser, M.L. 1998. Ediacara-type fossils in Cambrian sediments. Nature 393:567-569.

Jensen, S., Saylor, B.Z., Gehling, J.G., and Germs, G.J. 2000. Complex trace fossils from the terminal Proterozoic of Namibia. Geology 28:143146.

Jensen, S. and Runnegar, B.N. 2005. A complex trace fossil from the Spitskop Member (terminal Ediacaran-? Lower Cambrian) of southern Namibia. Geological Magazine 142:561-569. 
Jensen, S., Álvaro, J.J., and Palacios, T. 2019. Pre-conference fieldtrip, October 17-18, 2019: Ediacaran, Lower Palaeozoic and landscapes within the Villuercas-Ibores-Jara UNESCO Global Geopark. Guía de campo pre-congreso, 17-18 de Octubre de 2019: Ediacárico, Paleozoico Inferior y panorámicas en el Geoparque de la UNESCO Villuercas-Ibores-Jara. Estudios Geológicos 75: e120. DOI:10.3989/egeol.43725.575.

Kesidis, G, Slater, B.J., Jensen, S., and Budd, G. 2019. Caught in the act: priapulid burrowers in early Cambrian substrates. Proceedings of The Royal Society B 286: DOI:10.1098/rspb.2018.2505.

Konhauser, K. 2007. Introduction to Geomicrobiology. Blackwell Science. 425 pp. ISBN 978-0-632-05454-1.

Laing, B.A., Buatois, L.A., Mángano, M.G., Narbonne, G.M., and Gougeon, R.C. 2018. Gyrolithes from the Ediacaran-Cambrian boundary section in Fortune Head, Newfoundland, Canada: Exploring the onset of complex burrowing. Palaeogeography, Palaeoclimatology, Palaeoecology 495:171-185. DOI:10.1016/j.palaeo.2018.01.010.

Lawrence, J.R., Wolfaardt, G.M., and Korber, D.R. 1994. Determination of diffusion coefficients in biofilms by confocal laser microscopy. Applied and Environmental Microbiology 60:1166-1173.

Liu, A.G., McIlroy, D., and Brasier, M.D. 2010. First evidence for locomotion in the Ediacara biota from the 565 Ma Mistaken Point Formation, Newfoundland. Geology 38:123-126.

Liu, A.G., McIlroy, D., Matthews, J.J., and Brasier, M.D. 2011. A new assemblage of juvenile Ediacaran fronds from the Drook Formation, Newfoundland. Journal of the Geological Society 169:395-403. DOI:10.1144/0016-76492011-094.

Liu, A.G., Matthews, J.J., Menon, L.R., McIlroy, D., and Brasier, M.D. 2014. Haootia quadriformis n. gen., n. sp., interpreted as a muscular cnidarian impression from the Late Ediacaran period (approx. 560 Ma). Proceedings of The Royal Society B 281: DOI:10.1098/rspb.2014.1202.

Liu, A.G., Matthews, J.J., Menon, L.R., McIlroy, D., and Brasier, M.D. 2015. The arrangement of possible muscle fibres in the Ediacaran taxon Haootia quadriformis. Proceedings of The Royal Society B 282: DOI:10.1098/rspb.2014.2949.

Liu, A.G., Matthews, J.J., and McIlroy, D. 2016. The Beothukis/Culmofrons problem and its bearing on Ediacaran macrofossil taxonomy: evidence from an exceptional new fossil locality: Palaeontology 59:45-58. DOI: 10.1111/pala.12206.

Loenarz C., Coleman, M.L., Boleiniger, A., Schierwater, B., Holland, P.W.H., Ratcliffe, P.J., and Schofield, C.J. 2011. The hypoxia-inducible transcription factor pathway regulates oxygen sensing in the simplest animal, Trichoplax adhaerens. European Molecular Biology Reports 12:63-70

Mata, S.A. and Bottjer, D.J. 2009. Development of Lower Triassic wrinkle structures: Implications for the search for life on other planets. Astrobiology 9:895-906. DOI:10.1089/ast.2008.0290.

Matthews, J.J., Liu, A.G., Yang, C., McIlroy, D., Levell, B., and Condon, D.J. 2020. A chronostratigraphic framework for the rise of the Ediacaran macrobiota: New constraints from Mistaken Point Ecological Reserve, Newfoundland. Geological Society of America Bulletin 133:612624. DOI:10.1130/B35646.1.

McIlroy, D. 2004. Some ichnological concepts, methodologies, applications and frontiers. In: Mcllroy, D. (ed), The Application of Ichnology to Palaeoenvironmental and Stratigraphic Analysis. Geological Society, London, Special Publications, 228:3-27, DOI:10.1144/GSL.SP.2004.228.01.02

McIlroy, D. 2008. Ichnological analysis: The commonground between ichnofacies workers and ichnofabricanalysts. Palaeogeography, Palaeoclimatology, Palaeoecology 270:332-338.

Mcllroy, D. and Walter, M.R. 1997. A reconsideration of the biogenicity of Arumberia banksi Glaessner \& Walter. Alcheringia 21:79-80. DOI: $10.1080 / 03115519708619187$

McIlroy, D. and Brasier, M.D. 2017. Ichnological evidence for the Cambrian explosion in the Ediacaran to Cambrian succession of Tanafjord, Finnmark, northern Norway. In: Brasier, A.T., McIlroy, D. \& McLoughlin, N. (eds), Earth System Evolution and Early Life: A Celebration of the Work of Martin Brasier. Geological Society, London, Special Publications, 448:351-368.

McIlroy, D. and Logan, G.A. 1999. The impact of bioturbation on infaunal ecology and evolution during the Proterozoic - Cambrian transition. Palaios 14:58-72.

McIlroy, D., Jenkins, R.J.F., and Walter, M.R. 1997. The nature of the Proterozoic-Cambrian transition in the northern Amadeus Basin, central Australia. Precambrian Research 86:93-113. DOI:10.1016/S0301-9268(97)00044-2.

McIlroy, D., Crimes, T.P. and Pauley, J.C. 2005. Fossils and matgrounds from the Neoproterozoic Longmyndian Supergroup, Shropshire, U.K. Geological Magazine 142:441-455.

McIlroy, D., Brasier, M.D., and Lang, A.S. 2009. Smothering of microbial mats by macrobiota: Implications for the Ediacara biota. Journal of the Geological Society 166:1117-1121. DOI:10.1144/0016-76492009-073.

McIlroy, D., Hawco, J., McKean, C., Nicholls, R., Pasinetti, G., and Taylor, R. 2020. Palaeobiology of the reclining rangeomorph Beothukis from the Ediacaran Mistaken Point Formation of southeastern Newfoundland. Geological Magazine 2.452: 1-15. DOI:10.1017/S0016756820000941.

McIlroy, D., Dufour, S.C., Taylor, R., and Nicholls, R. 2021. The role of symbiosis in the first colonization of the seafloor by macrobiota: Insights from the oldest Ediacaran biota (Newfoundland, Canada). Biosystems 205:104413. DOI:10.1016/j.biosystems.2021.104413.

McMahon, S., Matthews, J.J., Brasier, A.T., and Still, J. 2021. Late Ediacaran life on land: desiccated microbial mats and large biofilm streamers. DOI: $10.1098 / \mathrm{rspb} .2021 .1875$.

Menon, L.R., McIlroy, D., and Brasier, M.D. 2017. 'Intrites' from the Ediacaran Longmyndian Supergroup, UK: a new form of microbiallyinduced sedimentary structure (MISS). In: Brasier, A.T., McIlroy, D., \& McLoughlin, N. (eds), Earth System Evolution and Early Life: A Celebration of the Work of Martin Brasier. Geological Society, London, Special Publications, vol. 448:271-283. DOI:10.1144/SP448.12.

Meyer, M., Xiao, S., Gill. B.C., Schiffabuer, J.D., Chen, Z., Zhou, C \& Yuan X. 2014. Interactions between Ediacaran animals and microbial mats: insights from Lamonte trevallis, a new trace fossil from the Dengjing Formation of South China. Palaeogeography, Palaeoclimatology, Palaeoecology 396, 62-74.

Miller, S.A. 1889. North American Geology and Paleontology for the Use of Amateurs, Students, and Scientists. Cincinnati: Western Methodist Book Concern. 664 pp.

Miller, W. III. 1991. Paleoecology of graphoglyptids. Ichnos 1:305-312.

Muñiz Guinea, F., Mangano, M.G., Buatois, L.A., Podeniene, V., Vintaned, J.A.V., Mayoral, E.J. 2014. Compound biogenic structures resulting from ontogenetic variation: An example from a modern dipteran. Spanish Journal of Palaeontology 29:83-94. DOI:10.7203/sjp.29.1.17491.

Narbonne, G.M. and Gehling, J.G. 2003. Life after snowball: The oldest complex Ediacaran fossils. Geology 31:27-30. DOI:10.1130/00917613(2003)031\%3C0027:LASTOC\%3E2.0.CO;2.

Narbonne, G.M., Myrow, P.M., Landing, E., and Anderson, M.M. 1987. A candidate stratotype for the Precambrian-Cambrian boundary, Fortune Head, Burin Peninsula, southeastern Newfoundland: Canadian Journal of Earth Sciences 24:1277-1293.

Noffke, N. 2000. Extensive microbial mats and their influences on the erosional and depositional dynamics of a siliciclastic cold-water environment (Lower Arenigian, Montagne Noire, France. Sedimentary Geology 136: 207-215. 
Noffke, N., Knoll, A.H., and Gritzinger, J.P. 2002. Sedimentary controls on the formation and preservation of microbial mat in siliciclastic deposits: a case study from the Upper Proterozoic Nama Group, Namibia. Palaios 17:533-544.

Olivero, E.B., López Cabrera, M.I., Malumián, N., and Torres Carbonell, P.J. 2010. Eocene graphoglyptids from shallow-marine, high-energy, organic-rich, and bioturbated turbidites, Fuegian Andes, Argentina. Acta Geologica Polonica 60:77-91.

Orłowski, S. and Żylinńska, A. 1996. Non-arthropod burrows from the Middle and Late Cambrian of the Holy Cross Mountains, Poland. Acta Palaeontologica Polonica 41:385-409.

Ortega, J.M., Ortega, J.A., Stein, J.R., and Julian, D. 2008. $\mathrm{H}_{2}$ S toxicity via oxidative damage in erythrocytes of a sulfide-tolerant marine invertebrate. The FASEB Journal 22:758.39. DOI:10.1096/fasebj.22.1_supplement.758.39.

Parry, L.A., Boggiani, P.C., Condon, D.J., Garwood, R.J., de M. Leme, J., McIlroy, D., Brasier, M.D., Trindade, R., Campanha, G.A.C., Pacheco, M.L.A.F., Diniz, C.Q.C., and Liu, A.G. 2017. Ichnological evidence for meiofaunal bilaterians from the terminal Ediacaran and earliest Cambrian of Brazil. Nature Ecology and Evolution 1:1455-1464. DOI:10.1038/s41559-017-0301-9.

Petersen, J.M. and Dubilier, N. 2009. Methanotrophic symbioses in marine invertebrates. Environmental Microbiology Reports 1: 319-335. DOI: $10.1111 / \mathrm{j} .1758-2229.2009 .00081 . x$.

Pflüger, F. 1999. Matground structures and redox facies. Palaios 14:25-39.

Prieto-Barajas, C.M., Valencia-Cantero, E., and Santoyo, G. 2018. Microbial mat ecosystems: Structure types, functional diversity, and biotechnological application. Electronic Journal of Biotechnology 31:48-56. DOI:10.1016/j.ejbt.2017.11.001.

Rona, P.A., Seilacher, A., de Vargas, C., Gooday, A.J., Bernhard, J.M., Bowser, S., Vetriani, C., Wirsen, C.O., Mullineaux, L., Sherrell, R., Grassle, J.F., Low, S., and Lutz, R.A. 2009. Paleodictyon nodosum: a living fossil on the deep-sea floor. Deep-Sea Research II 56:17001712 .

Runnegar, B. 1982. The Cambrian Explosion—animals or fossils. Journal of the Geological Society of Australia 29: 395-411.

Seilacher, A. 1962. Paleontological studies on turbidite sedimentation and erosion. Journal of Geology 70:227-234.

Seilacher, A. 1977. Pattern analysis of Paleodictyon and related trace fossils. In: T. P. Crimes, and J. C. Harper (eds), Trace fossils 2. Geological Journal, Special Issue 9:289-334. Seel House, Liverpool.

Seilacher, A. 1997. The meaning of the Cambrian explosion. In: Chen, J.-Y. and Seilacher, A. (eds), The Cambrian explosion and the fossil record, Bulletin of National Museum of Natural Science 10:1-9.

Seilacher, A. 1999. Biomat-related lifestyles in the Precambrian. Palaios 14:86-93. DOI:10.2307/3515363.

Seilacher, A., Buatois, L.A., and Mángano, M.G. 2005. Trace fossils in the Ediacaran-Cambrian transition: Behavioral diversification, ecological turnover and environmental shift. Palaeogeography, Palaeoclimatology, Palaeoecology 227:323-356. DOI:10.1016/j.palaeo.2005.06.003

Seilacher A. and MacClintock, C. 2005. Crinoid anchoring strategies for soft-bottom dwelling. Palaios 20:224-240.

Seilacher, A. and Hagadorn, J.W. 2010. Early molluscan evolution: Evidence from the trace fossil record. Palaios 25:565-575.

Severin, K.P., Culver, S.J., and Blanppied, C. 1982. Burrows and trails produced by Quinqueloculina impressa Reuss, a benthic foraminifera, in fine-grained sediment. Sedimentology 29:879-901.

Sheehan, P.M. and Harris, M.T. 2004. Microbialite resurgence after the Late Ordovician extinction. Nature 430:75-78. DOI:10.1038/nature02654

Sperling, E.A. and Vinther, J. 2010. A placozoan affinity for Dickinsonia and the evolution of late Proterozoic metazoan feeding modes. Evolution \& Development 12:201-209. DOI: 10.1111/j.1525-142X.2010.00404.x

Swinbanks, D. 1982. Palaeodictyon: the traces of infaunal xenophyophores? Science 218:47-49.

Taylor, R.S., Matthews, J.J., Nicholls, R., and McIlroy, D. A re-assessment of the taxonomy, palaeobiology and taphonomy of the rangeomorph organism Hapsidophyllas flexibilis from the Ediacaran of Newfoundland, Canada. Paläontologische Zeitschrift 95:187-207. DOI:10.1007/s12542-020-00537-4.

Uchman, A., Bromley, R.G. \& Leszczynski, S. 1998. Ichnogenus Treptichnus in Eocene flysch, Carpathians, Poland: taxonomy and preservation. Historical Biology 5: 269-275.

Uchman, A. 2004. Phanerozoic history of deep-sea trace fossils. In: D. McIlroy (ed), The application of ichnology to palaeoenvironmental and stratigraphic analysis. Geological Society of London Special Publication 228:125-139.

Walter, M. R. 1977. Interpreting Stromatolites: These fossils can tell us much about past organisms and environments if we can learn to decode their message. American Scientist 65:563-571.

Walter, M.R.W. and Heys, G. 1985. Links between the rise of the Metazoa and the decline of the stromatolites: Precambrian Research 29:149174.

White, D.C. 1983. Analysis of microorganisms in terms of quantity and activity in natural environments. Microbes in their natural environments: Society for General Microbiology Symposium 34:37-66.

Wood, R. and Erwin, D.H. 2017. Innovation not recovery: dynamic redox promotes metazoan radiations. Biological Reviews 93:863-873.

Wood, R.A., Poulton, S.W., Prave, A.R., Hoffman, K.-H., Clarkson, M.O., Guilbaud, R., Lyne, J.W., Tostevin, R., Bowyer, F., Penny, A.M., Curtis, A., and Kasemann, S.A. 2015. Dynamic redox conditions control late Ediacaran metazoan ecosystems in the Nama Group, Namibia. Precambrian Research 261:252-271. DOI:10.1016/j.precamres.2015.02.004.

Wood, R., Liu, A.G., Bowyer, F., Wilby, P.R., Dunn, F.S., Kenchington, C.G., Hoyal Cuthill, J.F., Mitchell, E.G., and Penny, A. 2019. Integrated records of environmental change and evolution challenge the Cambrian Explosion: Nature Ecology \& Evolution 3:528-538. DOI:10.1038/s41559-019-0821-6.

Xiao, S.-H. and Laflamme, M. 2009. On the eve of animal radiation: phylogeny, ecology, and evolution of the Ediacara biota. Trends in Ecology and Evolution 24:31-40.

Zhu, M.-Y., Zhuravlev, A.Y., Wood, R.A., Zhao, F.-C. and Sukhov, S.S. 2017. A deep root for the Cambrian explosion: implications of new bioand chemostratigraphy from the Siberian Platform. Geology 45:459-462. 